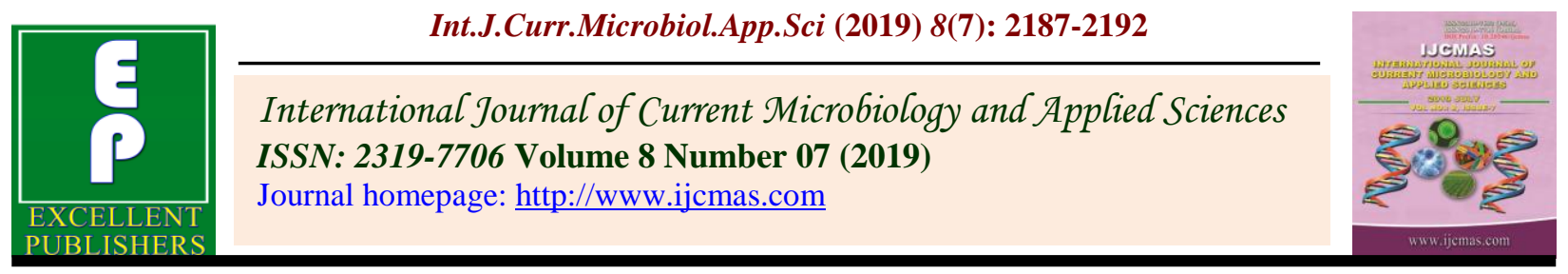

Original Research Article

https://doi.org/10.20546/ijcmas.2019.807.265

\title{
Checklist of Macro-Fungi from Baramati Area of Pune District, MS, India
}

\author{
Anuradha K. Bhosale*, Vivek Kadam, Prasad Bankar, Sandhya Shitole, Sourabh \\ Chandankar, Sujit Wagh and M.B. Kanade
}
P. G. Research Center, Department of Botany, Tuljaram Chaturchand College of Arts, Science and Commerce, Baramati, Dist. Pune - 413 102, Maharashtra, India

*Corresponding author

\begin{tabular}{|l|}
\hline Ke y w or d s \\
Macro-fungi \\
diversity
\end{tabular}

A B S T R A C T

Macro-fungi are the fungal species that produce fruiting bodies visible to naked eyes and occurs widely in the rainy season. The macro-fungi plays important role in nutrient dynamics, soil health, as pollution indicator, species mutualism and its interaction and even has its economic role in carbon cycling and the mobilization of nitrogen and phosphorous. Present investigation emphasizes on study of macro-fungi from Baramati area of Pune district of Maharashtra. During the study frequent field visits, listing of genera and their species, identification and photography has done. In the checklist total 64 fungal species belonging to 37 genera, 03 sub-divisions, 13 orders and 23 families were reported. The contribution of Basidiomycotina fungi was $90 \%$ followed by Ascomycotina (7.8\%) and Zygomycotina $(1.6 \%)$.

\section{Introduction}

Fungi are amongst the most important organisms in the world, not only because of their vital role in ecosystem functions (Blackwell, 2011) but also for their influence on humans and human-related activities (Mueller and Bills, 2004). They are used in the bioremediation of industrial waste and in the accumulation of heavy metals from the environment (Tuli et al., 2014). According to Hawksworth (2004) there are approximately 1.5 million species of fungi found on the Earth. Sarbhoy et al., (1996) reported more than 27000 fungal species throughout the India. The number of mushroom species alone, recorded in the world were 41,000 of which approximately 850 species were recorded from India (Deshmukh, 2004) mostly belonging to gilled mushrooms. The macrofungi having large fructifications, visible to naked eyes and include large observable spore bearing structure. They have worldwide in distribution and can grow in wide range of habitats and abundant in spring and autumn due to favorable climate and low in hot and dry seasons (Pilz and Molina, 2001). Macrofungi are rich in mineral nutrients as well as 
rich in carbohydrates (Fasidi, 1996). Chang and Buswell (1996) reported that mushroom have antitumour, anticancer, anticholesterol and antihemorrhage properties. Considering the economic aspects and the significant role of fungi several countries are working hard for their documentation and screening them for various products (Mueller et al., 2004).

Baramati is one of the major agricultural tehsil in Pune district, Maharashtra state of India. It lies between $18.15^{\circ} \mathrm{N}$ latitude and $74.58^{\circ} \mathrm{E}$ longitude with the wide climatic diversity. The diverse climatic conditions and ecological habitats of Baramati make this area a natural habitat for the growth and development of large number of macro-fungi. Considering these things, the present investigation is trying to focus on the diversity of macro-fungi in and around Baramati area of Pune district of Maharashtra, India.

\section{Materials and Methods}

The survey and collection of macro-fungi was carried out from Baramati area during August, 2017 to January, 2019. While survey and collection the habitat, habit, type of substratum, colour, size and odour of macrofungi were recorded. Field photography of fungi was also done. Fungal material was brought to the laboratory using clean polythene bags and stored properly for their further analysis. Macroscopic and microscopic characters of their fruiting bodies were studied by using laboratory lenses and light microscope. The fungi were identified by using standard literature (Ranadive et al., 2011, Gogoi and Parkash, 2015) and classified according to classification system of Ainsworth (1973).

\section{Results and Discussion}

Present investigation emphasizes on study of macro-fungi from Baramati area of Pune district of Maharashtra. In the checklist total 64 macro-fungal species belonging to 37 genera, 03 sub-divisions, 13 orders and 23 families were reported (Table 1). The Basidiomycotina fungi having highest contribution i.e. $90 \%$ followed by Ascomycotina (7.8\%) and Zygomycotina (1.6\%). Agaricales was found as predominant order compared to other orders. The number of species in Agaricales was - 31, followed by Polyporales (17), Auriculariales and Xylariales (3), Cantharellales and Pezizales (2), Geastrales, Boletales, Phallales, Hymenochaetales, Gomphales and Mucorales (1). Coprinus (8 species) and Agaricus (6 species) were most abundantly found genera on the contrary Pilobolus (1 species) was occurred rarely. Collected fungi showed lot of diversity in their habitats as 47 species was found as saprophytic followed by parasitic (8), wood rotting (06), coprophilous (02) and symbiotic (01). It is interesting to note that, among the collected fungi we have found 32 edible (wild and traditional), 17 decomposers, 12 - medicinal and 1 ectomycorrhizal species (Table 1).

According to Hawksworth (2004) fungi constitute the third important functional segment as decomposers, symbionts and pathogens. In forest ecosystems, macro-fungi may function as decomposers of organic matter, form mycorrhizal associations with trees, occur as parasites or pathogens and are food resources for various organisms (Crabtree et al., 2010).

Fungi enhance the capability of the plants to take up and utilize nutrients, strengthen the self-defense ability, promote plant growth and improve soil quality (Zhang et al., 2010). According to Dwivedi et al., (2017) macrofungi having a rich nutritional value, due to their high quality proteins and out of 60,000 species of fungi, described throughout world, 10,000 species are fleshy mushrooms. 
Int.J.Curr.Microbiol.App.Sci (2019) 8(7): 2187-2192

Table.1 Checklist of macro-fungi from Baramati area

\begin{tabular}{|c|c|c|c|c|c|}
\hline Sr No. & Name of Fungi & Family & Order & Class & Sub Division \\
\hline 1 & Pilobolus crystallinus & Pilobolaceae & Mucorales & Mucoromycetes & Zygomycotina \\
\hline 2 & Daldinia concentric & Xylariaceae & Xylariales & Sordariomycetes & Ascomycotina \\
\hline 3 & Xylaria hypoxylon & Xylariaceae & Xylariales & Sordariomycetes & Ascomycotina \\
\hline 4 & Hypoxylon coccineum & Xylariaceae & Xylariales & Sordariomycetes & Ascomycotina \\
\hline 5 & Peziza imnaea & Pezizaceae & Pezizaceales & Pezizomycetes & Ascomycotina \\
\hline 6 & Ascobolus scatigenus & Ascobolaceae & Pezizaceales & Pezizomycetes & Ascomycotina \\
\hline 7 & Ganoderma lucidum & Ganodermataceae & Polyporales & Agaricomycete & Basidiomycotina \\
\hline 8 & Ganoderma sessile & Ganodermataceae & Polyporales & Agaricomycete & Basidiomycotina \\
\hline 9 & Ganoderma resinaceum & Ganodermataceae & Polyporales & Agaricomycete & Basidiomycotina \\
\hline 10 & Pleurotus ostreatus & Pleurotaceae & Agaricales & Agaricomycete & Basidiomycotina \\
\hline 11 & Volvariella argentina & Pluteaceae & Agaricales & Agaricomycete & Basidiomycotina \\
\hline 12 & Leucocoprinus badhamii & Agaricaceae & Agaricales & Agaricomycete & Basidiomycotina \\
\hline 13 & Lepiota aspera & Agaricaceae & Agaricales & Agaricomycete & Basidiomycotina \\
\hline 14 & Lepiota brunneoincarnata & Agaricaceae & Agaricales & Agaricomycete & Basidiomycotina \\
\hline 15 & Lepiota magnispora & Agaricaceae & Agaricales & Agaricomycete & Basidiomycotina \\
\hline 16 & Lepiota procera & Agaricaceae & Agaricales & Agaricomycete & Basidiomycotina \\
\hline 17 & Lycoperdon umbrinum & Agaricaceae & Agaricales & Agaricomycete & Basidiomycotina \\
\hline 18 & Lycoperdon utriforme & Agaricaceae & Agaricales & Agaricomycete & Basidiomycotina \\
\hline 19 & Lycoperdon perlatum & Agaricaceae & Agaricales & Agaricomycete & Basidiomycotina \\
\hline 20 & Lycoperdon pyriforme & Agaricaceae & Agaricales & Agaricomycete & Basidiomycotina \\
\hline 21 & Agaricus augustus & Agaricaceae & Agaricales & Agaricomycete & Basidiomycotina \\
\hline 22 & Agaricus californicus & Agaricaceae & Agaricales & Agaricomycete & Basidiomycotina \\
\hline 23 & Agaricus subrutilescens & Agaricaceae & Agaricales & Agaricomycete & Basidiomycotina \\
\hline 24 & Agaricus porphyrocephalus & Agaricaceae & Agaricales & Agaricomycete & Basidiomycotina \\
\hline 25 & Agaricus diminutivus & Agaricaceae & Agaricales & Agaricomycete & Basidiomycotina \\
\hline 26 & Agaricus lutosus & Agaricaceae & Agaricales & Agaricomycete & Basidiomycotina \\
\hline 27 & Coprinus comatus & Agaricaceae & Agaricales & Agaricomycete & Basidiomycotina \\
\hline 28 & Coprinus logapus & Agaricaceae & Agaricales & Agaricomycete & Basidiomycotina \\
\hline 29 & Coprinus hiascens & Agaricaceae & Agaricales & Agaricomycete & Basidiomycotina \\
\hline 30 & Coprinus fimetarius & Agaricaceae & Agaricales & Agaricomycete & Basidiomycotina \\
\hline 31 & Coprinus calyptratus & Agaricaceae & Agaricales & Agaricomycete & Basidiomycotina \\
\hline 32 & Coprinus stercoreus & Agaricaceae & Agaricales & Agaricomycete & Basidiomycotina \\
\hline 33 & Coprinus patouilardii & Agaricaceae & Agaricales & Agaricomycete & Basidiomycotina \\
\hline 34 & Coprinus plicatilis & Agaricaceae & Agaricales & Agaricomycete & Basidiomycotina \\
\hline 35 & Marasmius bulliardii & Marasmiaceae & Agaricales & Agaricomycete & Basidiomycotina \\
\hline 36 & Cyathus striatus & Nidulariaceae & Agaricales & Agaricomycete & Basidiomycotina \\
\hline 37 & Clavaria amoena & Clavariaceae & Agaricales & Agaricomycete & Basidiomycotina \\
\hline 38 & Clavaria pyxidate & Clavariaceae & Agaricales & Agaricomycete & Basidiomycotina \\
\hline 39 & Armillaria tabescens & Physalacriaceae & Agaricales & Agaricomycete & Basidiomycotina \\
\hline 40 & Termitomyces microcarpus & Lyophyllaceae & Agaricales & Agaricomycete & Basidiomycotina \\
\hline 41 & Polyporus arcularius & Polyporaceae & Polyporales & Agaricomycete & Basidiomycotina \\
\hline 42 & Polyporus squamosus & Polyporaceae & Polyporales & Agaricomycete & Basidiomycotina \\
\hline 43 & Polyporus umbellatus & Polyporaceae & Polyporales & Agaricomycete & Basidiomycotina \\
\hline 44 & Trametes hirsute & Polyporaceae & Polyporales & Agaricomycete & Basidiomycotina \\
\hline 45 & Trametes versicolor & Polyporaceae & Polyporales & Agaricomycete & Basidiomycotina \\
\hline 46 & Lenzites betulina & Polyporaceae & Polyporales & Agaricomycete & Basidiomycotina \\
\hline 47 & Fomes fomentarius & Polyporaceae & Polyporales & Agaricomycete & Basidiomycotina \\
\hline 48 & Hexagonia tenuis & Polyporaceae & Polyporales & Agaricomycete & Basidiomycotina \\
\hline 49 & Lentinus tigrinus & Polyporaceae & Polyporales & Agaricomycete & Basidiomycotina \\
\hline 50 & Tyromyces stipticus & Polyporaceae & Polyporales & Agaricomycete & Basidiomycotina \\
\hline 51 & Loweporus sp. & Polyporaceae & Polyporales & Agaricomycete & Basidiomycotina \\
\hline 52 & Daedalea quercina & Fomitopsidaceae & Polyporales & Agaricomycete & Basidiomycotina \\
\hline 53 & Fomitopsis pinicola & Fomitopsidaceae & Polyporales & Agaricomycete & Basidiomycotina \\
\hline 54 & Fomitopsis feei & Fomitopsidaceae & Polyporales & Agaricomycete & Basidiomycotina \\
\hline 55 & Geastrum saccatum & Geastraceae & Geastrales & Agaricomycete & Basidiomycotina \\
\hline 56 & Auricularia auricula & Auriculariaceae & Auriculariales & Agaricomycete & Basidiomycotina \\
\hline 57 & Auricularia americana & Auriculariaceae & Auriculariales & Agaricomycete & Basidiomycotina \\
\hline 58 & Auricularia polytricha & Auriculariaceae & Auriculariales & Agaricomycete & Basidiomycotina \\
\hline 59 & Ramaria formosa & Gomphaceae & Gomphales & Agaricomycete & Basidiomycotina \\
\hline 60 & Boletus edulis & Boletaceae & Boletales & Agaricomycete & Basidiomycotina \\
\hline 61 & Cantharellus cibarius & Cantharellaceae & Cantharellales & Agaricomycete & Basidiomycotina \\
\hline 62 & Hydnum repandum & Hydnaceae & Cantharellales & Agaricomycete & Basidiomycotina \\
\hline 63 & Phallus sp. & Phallaceae & Phallales & Agaricomycete & Basidiomycotina \\
\hline 64 & Phellinus rimosus & Hymenochaetaceae & Hymenochaetales & Agaricomycete & Basidiomycotina \\
\hline
\end{tabular}


Ranadive et al., (2011) is pioneer worker in Aphyllophorales of Maharashtra as well as India, emphasizes on majority all aspects of Aphyllophorales and concluded that i) Aphyllophorales are the major source of biologically active natural products among the species of the diverse fungal phylum Basidiomycota ii) many species like Trametes versicolor, Laetiporus sulphureus and Ganoderma having rich variety of active secondary metabolites and polysaccharides and iii) several new chemical compounds isolated from polypores are proved to have significant antimicrobial activities. Devkota (2006) described the value of Cordyceps sinensis and regarded internationally as Himalayan Viagra. This Himalayan treasure species used by indigenous people for the treatment of different diseases like diarrhea, headache, cough, rheumatism, liver disease and also as an aphrodisiac and tonic. Muraleedharan et al., (1995) reported that macrofungi were considered ideal for the purpose of evaluation as biosorbents as it has exhibit high biosorptive potentials.

Monsoon and winter climates are the ideal conditions for the growth the development of macro-fungi (Yemul et al., 2019). Walting and Abraham (1992) found that, Jammu and Kashmir possess a prime place in the variety and galaxy of macro-fungi due to wide agroclimatic variations, diverse physiography and undulating topography. Study of Aphyllophorales fungi from Western Ghats of Maharashtra was carried out by Ranadive et $a l$., (2011). During their work they concluded that, the heavy rainfall and high humidity favours the growth of aphyllophoraceous fungi. They published checklist of the 256 species of aphyllophoraceous fungi including 170 species from 10 poroid families and 86 species from 20 non-poroid families. Gogoi and Parkash (2015) published a checklist of gilled mushrooms from Hollongapar Gibbon Wildlife Sanctuary, Assam, India and reported 138 species of gilled mushrooms belonging to 48 genera, 23 families. They found that the order Agaricales was the highest number of species i.e. 113, followed by Russulales (14), Polyporales (5), Cantharellales (4) and Boletales (2). Diversity of gasteroid fungi (Basidiomycota) from Hollongapar Gibbon Wildlife Sanctuary, Jorhat, Assam, India was studied by Gogoi and Vipin (2015) and reported 22 gasteroid fungal species belongs to 9 genera, 4 families, 4 orders, 2 sub-classes and 1 class. Furthermore, they concluded that the family Agaricaceae (8 sp.) was highly dominant from the study site followed by Phallaceae (7 sp.), Geastraceae (4 sp.), and Sclerodermataceae (3 sp.).

Natarajan et al., (2005) documented 25 species of ectomycorrhizal fungi in Kadamakkal Reserve Forest of Kodagu, Karnataka. Swapna et al., (2008) enumerated 778 species of macro-fungi from Shimoga District of Karnataka. Mohanan (2011) reported 550 species of macro-fungi from Kerala. Farook et al., (2013) compiled a literature-based checklist of agarics with 616 species occurring in Kerala State. Verma et al., (2008) described forest fungi of central India in details and furthermore Verma (2014) again reported 282 species of Basidiomycetes from central India.

The present attempt has been concluded that, Baramati area of Pune district of Maharashtra having tremendous diversity of macro-fungi. The Basidiomycotina group showed highest contribution compared to Ascomycotina. Agaricales and Polyporales were found as dominant orders. They can luxuriantly available in rainy and cold climatic conditions. These situations are ideal for their growth, development and sporulation. These fungi having very important potential applications like edibles, medicinal, symbionts and decomposers. 


\section{Acknowledgements}

Authors are sincerely thankful to Dr. Chandrashekhar Murumkar, Principal and Head, P. G. Research Center, Department of Botany, Tuljaram Chaturchand College of Arts, Science and Commerce, Baramati, Dist. Pune, MS, India for his constant guidance and encouragement.

\section{References}

Blackwell Meredith (2011). The fungi: 1, 2, 3 .. 5.1 million species? American Journal of Botany, 98(3): 426-438.

Chang, S. T. and Buswell, J. A. (1996). Mushroom nutriceuticals. World $J$. Microb. Biotechnol. 12, 473- 476.

Crabtree, Chiristopher, D., Keller, Harold, W., Ely, Joseph, S. (2010). Macro-fungi are associated with vegetation an soils at $\mathrm{Ha} \mathrm{Ha}$ Tonka State Park, Missouri. Mycologia, 102(6):1229-1239.

Deshmukh, S.K. (2004). Biodiversity of tropical basidiomycetes as sources of novel secondary metabolites, In: Jain, P.C. (ed.). Microbiology and Biotechnology for Sustainable Development. CBS Publishers and Distributors, New Delhi: 121-140.

Devkota, S. (2006). Yarsagumba [Cordyceps sinensis (Berk.) Sacc.]; traditional utilization in Dolpa District, Western Nepal. Our Nature, 4: 48-52.

Dwivedi Sandhya, Singh Surendra, Chauhan UK and Tiwari Mahendra Kumar (2017). Biodiversity studies on macro fungi with special reference to order Agaricales: Indian scenario. Journal of Bacteriology \& Mycology: Open Access, 5(6): 00159.

Farook, V.A., Khan, S.S., Manimohan, P. (2013). A checklist of agarics (gilled mushrooms) of Kerala State, India. Mycosphere, 4(1), 97-131.
Fasidi Isola O. (1996). Studies on Volvariella esculenta (Mass) Singer: cultivation on agricultural wastes and proximate composition of stored mushrooms. Food Chemistry, 55(2): 161-163.

Gogoi Girish and Parkash Vipin (2015). A checklist of gilled mushrooms (Basidiomycota: Agaricomycetes) with diversity analysis in Hollongapar Gibbon Wildlife Sanctuary, Assam, India. Journal of Threatened Taxa, 7(15): 8272-8287.

Gogoi, G. and Vipin, P. (2015). Diversity of Gasteroid fungi (Basidiomycota) in Hollongapar Gibbon wildlife sanctuary, Jorhat, Assam, India. Current Research in Environmental \& Applied Mycology, 5 (3): 202-212.

Hawksworth, D.L. (2004). Fungal diversity and its implifications for Genetic Resource collections. Studies in Mycology, 50:9-18.

Mohanan, C. (2011). Macro-fungi of Kerala. Kerala Forest Research Institute, Hand Book 27, Kerala, India: 597.

Mueller, G.M, Bills, G.F, Foster, M.S. (2004). Biodiversity of fungi: inventory and monitoring methods. Elsevier Academic Press, San Diego.

Mueller, G.M., Foster, M., Bills, G.F. (2004). Biodiversity of fungi inventory and monitoring methods. Burlington: Academic Press: 777.

Muraleedharan, T. R., Iyengar, Leela and Venkobachar, C. (1995). Screening of Tropical Wood-Rotting Mushrooms for Copper Biosorption. Applied and Environmental Microbiology, 61(9):3507-8.

Natarajan, K., Senthilarasu, G., Kumaresan, V. and Riviere, T. (2005). Diversity in ectomycorrhizal fungi of a dipterocarp forest in Western Ghats. Current Science 88, 1893-1895.

Pilz David and Molina Randy (2001). Commercial harvests of edible 
mushrooms from the forests of the Pacific Northwest United States: issues, management and monitoring for sustainability. Forest Ecology and Management, 5593: 1-14.

Ranadive, K.R., Vaidya, J.G., Jite, P.K., Ranade, V.D., Bhosale, S.R., Rabba, A.S., Hakimi, M., Deshpande, G.S., Rathod, M.M., Forutan, A., Kaur, M., Naik-Vaidya, C.D., Bapat, G.S. and Lamrood, P. (2011). Checklist of Aphyllophorales from the Western Ghats of Maharashtra State, India. Mycosphere, 2: 91-114.

Sarbhoy, A.K., Agarwal, D.K. and Varshney, J.L. (1996). Fungi of India (19821992). CBS Publishers and Distributors, New Delhi: 350.

Swapna, S., Syed Abrar and Krishnappa, M. (2008). Diversity of Macro-fungi in Semi-Evergreen and Moist Deciduous Forest of Shimoga District-Karnataka, India. Journal of Mycology and Plant Pathology, 38: 1.

Tuli, H.S., Sandhu, S.S. and Sharma, A.K. (2014). Pharmacological and therapeutic potential of Cordyceps with special reference to Cordycepin. Biotech, 4(1): 1-2.

Verma, R.K., Sharma, N., Soni, K.K., Jamaluddin. (2008). Forest fungi of Central India. International Book Distributing Co., Lucknow.

Verma, Ram. (2014). Biodiversity and Conservation of Forest Fungi of Central India. Microbial Diversity and Biotechnology in Food Security: 543559.

Walting, R. and Abraham, S.P. (1992). Ectomycorrhizal fungi of Kashmir forest. Mycorrhiza, 2: 81-87.

Yemul, N.B., Kanade, M.B. and Murumkar, C.V. (2019). Comprehensive Account of Leucophellinus hobsonii (Berk. ex Cooke) Ryvarden (Schizoporaceae) A Poroid species from Ratnagiri district of Western Ghats of India. Indian Forester, 145 (1): 48-51.

Zhang F., Shen J., Zhang J., Zuo Y., Li L., Chen X. (2010). Rhizosphere processes and management for improving nutrient use efficiency and crop productivity: implications for China. Advances in Agronomy, 107: 1-32.

\section{How to cite this article:}

Anuradha K. Bhosale, Vivek Kadam, Prasad Bankar, Sandhya Shitole, Sourabh Chandankar, Sujit Wagh and Kanade, M.B. 2019. Checklist of Macro-Fungi from Baramati Area of Pune District, MS, India. Int.J.Curr.Microbiol.App.Sci. 8(07): 2187-2192. doi: https://doi.org/10.20546/ijcmas.2019.807.265 